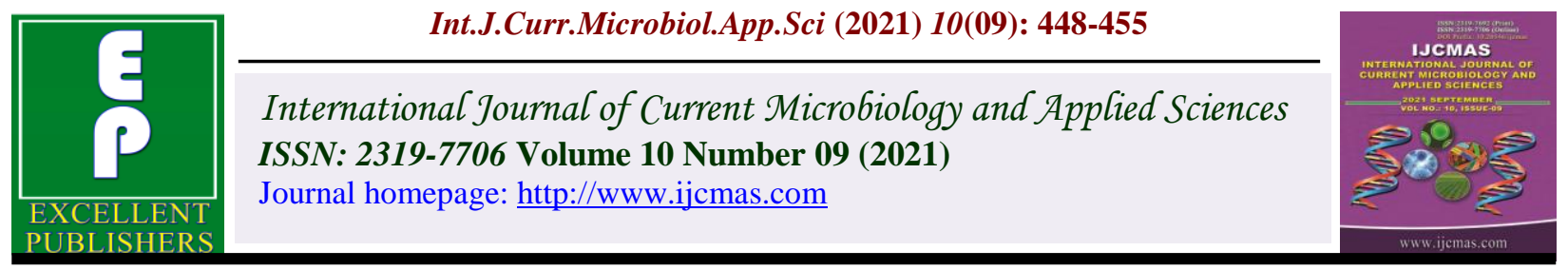

\title{
Levels of Available Zinc in Soil of Teaching and Research Farm Modibbo Adama University, Yola, North East Nigeria
}

\author{
U. Bapetel ${ }^{1 *}$, M. L. Bubarai ${ }^{2}$, A. M. Tahir ${ }^{1}$ and N. A. Abdulkadir ${ }^{3}$ \\ ${ }^{1}$ Department of Soil Science, Modibbo Adama University, Yola, Adamawa State, Nigeria \\ ${ }^{2}$ Department of Soil Science and Agricultural Chemistry, Sam Higgin Bottom University of \\ Agriculture Science and Technology, Prayagraj, India \\ ${ }^{3}$ Department of Soil Science, Kano University of Science and Technology, \\ Wudil, Kano State, Nigeria \\ *Corresponding author
}

\section{A B S T R A C T}

Keywords

Zinc, surface soil, subsurface soil, soil properties

Article Info

Accepted:

15 August 2021

Available Online:

10 September 2021
A study was conducted to assess the status of available zinc in soil of Teaching and Research Farm, Modibbo Adama University, Yola North East, Nigeria. Ten soil samples were collected from $0-20$ and $20-50 \mathrm{~cm}$ depths to reflect the soil of the study area. The soils were analysed following standard laboratory procedures. Result obtained showed that the soils were sandy loam to sandy clay loam, slightly acidic (mean $=6.4-$ surface; 6.5 - subsurface soils), very low OC content (mean $=0.35 \%-$ surface; $0.27 \%$ - subsurface soils), low to medium Total $\mathrm{N}$ and exchangeable bases. Zinc was generally low to medium (range $=0.18-$ $1.71 ;$ mean $=1.12 \%$ in surface soils, and range $=0.32-2.71 ;$ mean $=1.35$ $\%$ in subsurface soils). Zinc is not correlated with most of the soil properties in both soil depths. In surface soil, a positively correlation with potassium $\left(\mathrm{r}=0.702^{*}\right)$ was observed and negative correlation with Total $\mathrm{N}$ $\left(r=-0.634^{*}\right)$ in subsurface soils. It is recommended that for successful and profitable crop production, application of inorganic fertilizers plus zinc and organic material should be encouraged.

\section{Introduction}

Zinc is a metallic micronutrient element that is necessary for plant growth and it is required in extremely small quantity. Even though zinc is required in minute quantity, it has the same agronomic importance as macronutrients and play vital roles in growth of plants (Nazif et al., 2006). Zinc increases yield of crops, functions as an enzyme activator in 
carbohydrate metabolism and protein formation (Schulte, 2004), plays an important role in auxin production; assist in the utilization of phosphorus and nitrogen in plants; involved in biosynthesis of indole acetic acid (IAA) and tryptophane (Alam and Raza, 2001; FFD, 2002). Studies carried out so far have revealed zinc deficiency in some Nigerian savanna soils (Lombin, 1983). Low level of available $\mathrm{Zn}$ was reported by Mustapha et al., (2011). On a global study Sillanpää (1982) reported generally low to deficient levels of $\mathrm{Zn}$ in a number of soils from Nigeria.

In Nigeria with the increasing human and animal population, and policy of the Government to increase food production, farmers have abandoned the traditional practice of shifting cultivation to modern form of agriculture which involved use of high yielding crop varieties that take up many nutrients from the soil and cause deficiency of micronutrients. Similarly, the current fertilizer recommendation for crops in Northern Nigeria is only for macronutrients; continuous application of one or two macronutrients may in due course deplete the soil reserve of other nutrients and limit the crop performance (Oyinlola and Chude, 2010). Therefore for a successful implementation of scientific agricultural, assessing of nutrient status of the soil including zinc is necessary, hence this study was taken with the following objectives: (1) To determine the contents of available $\mathrm{Zn}$ in the soils, and \{2) To investigate the relationship between zinc and soil properties

\section{Materials and Methods}

\section{Study Area}

The study was carried out in Teaching and Research Farm, Modibbo Adama University, Yola North East, Nigeria, it is located on latitude $9^{0} 14^{\prime} \mathrm{N}$ and longitude $12^{0} 38^{\prime} \mathrm{E}$ at an altitude of $158.8 \mathrm{~m}$ above sea level. It falls within Northern Guinea Savannah zone that is characterized by high grass land with many shrubs and few trees, it has a distinct wet and dry seasons. Average annual rainfall is 958 $\mathrm{mm}$ which is characterized by one peak period usually attained in August. The relative humidity is very low between January and March $(20-30 \%)$, but with the onset of rainfall in April it starts to increase up to a peak of $80 \%$ in August and September (Musa, 2006). The temperature is high throughout the year, in dry season the mean daily temperature is about $39.7^{\circ} \mathrm{C}$ in April, the minimum temperature could go down as low as $15.2^{\circ} \mathrm{C}$ in January (Adebayo and Tukur, 1999). Soil types of the area are mainly Alfisols and Inceptisols with slightly acidic to neutral in soil $\mathrm{pH}$, low organic carbon, total $\mathrm{N}$, available $\mathrm{P}, \mathrm{CEC}$, and low to medium percentage base saturation (Musa, 2006).

\section{Soil Sampling}

Sampling locations were selected to reflect the soil of the study area, Random soil sampling method was used to collect ten soil samples in both surface $(0-20)$ and subsurface $(20-50$ $\mathrm{cm})$ soil depths. Soil auger was used to collect soil samples from each of the sampling point. The soil samples collected were properly labelled and stored in new plastic polythene bags and taken to the laboratory. Each sample was separately dried in air inside the laboratory and the ground using porcelain pestle and mortar, sieved with $2 \mathrm{~mm}$ sieve and the fine soil fraction was used for laboratory analysis

\section{Laboratory Analysis}

The soil samples were analysed for some physical and chemical properties of soil including zinc using standard laboratory procedures.. Particle size analysis was determined using the Bouyoucous hydrometer 
method (Gee and Bauder, 1986). Soil pH was measured in 1:2.5 soil/water suspension using glass electrode $\mathrm{pH}$ meter. Organic carbon was determined by the dichromate wet oxidation method of Walkley and Black (Nelson and Sommers, 1982). Total nitrogen was determined by Micro-kjeldah digestion technique method (Bremner, 1996). Available $\mathrm{P}$ was determined by Bray 1 method (Bray and Kurtz, 1945). Exchangeable bases were extracted by the neutral ammonium acetate procedure buffered at pH 7.0 (Grant, 1982). The amount of $\mathrm{K}$ and $\mathrm{Na}$ in the extract were determined using flame photometer with appropriate filters while $\mathrm{Mg}$ and $\mathrm{Ca}$ were determined by EDTA titrimetric method, exchangeable acidity $(\mathrm{Al}+\mathrm{H})$ was determined using $1 \mathrm{~N} \mathrm{KCl}$ method (Grant, 1982). Effective CEC was the summation of total exchangeable bases (CEC) and total exchangeable acid. Available zinc was extracted with $0.01 \mathrm{M} \mathrm{HCl}$ solution (Osiname et al., 1973) and determined on atomic absorption spectrophotometer (AAS) model BGP - 210 Buck Scientific at wavelength of $213.9 \mathrm{~nm}$

\section{Statistical analysis}

Data obtained were subjected to simple descriptive statistic including minimum, maximum, and mean, of some of the physical and chemical properties of soil. SARS Statistics software package Version 9.4 was used to analyze the correlation between zinc and physical and chemical properties of soil

\section{Results and Discussion}

Results of some physical properties of soils studied are presented in Table 1. Particle size distribution of the soils indicated that the textural class ranged from sandy loam to sandy clay loam. Sand ranged from 55.4 to $80.2 \%$. Silt ranged from 6.0 to $17.4 \%$, while clay ranged from 18.3 to $28.7 \%$. The soils have relatively high sand (mean $=68.5 \%$ ) in surface soils while clay was relatively high (mean $=19.8 \%)$ in subsurface soil. Sand content decreased with soil depth while silt and clay content increased with soil depth. This is expected as some of the increase with depth in clay may be as a result of removal of the fraction by surface run-off and also by illuviation (Voncir et al., 2008).

The soils are slightly acidic, the $\mathrm{pH}$ in water ranged from 6.0 to 6.9 with a mean of 6.4 in surface soil (Table 2), while in subsurface soil, the $\mathrm{pH}$ ranged from 5.9 to 6.8 with a mean of 6.5 (Table 3).

The organic carbon (OC) contents ranged from 0.19 to $0.60 \%$ with a mean of $0.35 \%$ in surface soil, while in subsurface soil, OC ranged from 0.17 to $0.35 \%$ with a mean of $0.27 \%$, these values of OC fell within the very low to low fertility classes for Northern Nigerian savanna soils. This would suggest that the soils would be prone to leaching of nutrients (Oyinlola and Chude, 2010).

The total $\mathrm{N}$ contents of the soils vary from $0.08-0.14 \%$ in surface soil, and from $0.08-$ $0.12 \%$ in subsurface soil, indicating total $\mathrm{N}$ varies from low to moderately low fertility class. Available $\mathrm{P}$ contents in the soils vary from $5.6-42.0 \mathrm{mg} \mathrm{kg}^{-1}$ in surface soil and from $6.0-19.0 \mathrm{mg} \mathrm{kg}^{-1}$ in subsurface soil indicating low to medium available $\mathrm{P}$ fertility classes (Enwezor et al., 1990). Bapetel et al., (2021) also reported low OC, total $\mathrm{N}$ and Available $\mathrm{P}$ in soils elsewhere in Yola and (Musa, 2006) in the same area. The values of exchangeable cations $\mathrm{Ca}^{2+}, \mathrm{Mg}^{2+}$, and $\mathrm{K}^{+}$are moderate, while $\mathrm{Na}^{+}$was low in both soil depths. The principal saturating cations in both the soil depths is $\mathrm{Ca}^{2+}$, followed by $\mathrm{Mg}^{2+}$.

In surface soils, $100 \%$ of soils have low CEC, while only $10 \%$ of soils in subsurface depth have moderate CEC level. 


\section{Zinc status}

The available $\mathrm{Zn}$ content ranged from 0.18 to $1.71 \mathrm{mg} \mathrm{kg}^{-1}$ with a mean of $1.12 \mathrm{mg} \mathrm{kg}^{-1}$ in surface soil (Table 2), while in subsurface soil available $\mathrm{Zn}$ ranged from 0.32 to $2.71 \mathrm{mg} \mathrm{kg}^{-1}$ with a mean of $1.35 \mathrm{mg} \mathrm{kg}^{-1}$, indicating low to medium content of zinc in both soil depths. The low zinc content was also reported by Isa
(2017) and Mustapha et al., (2011). In surface soils, $20 \%$ of soils have low level of available $\mathrm{Zn}$, while only $10 \%$ of soils in subsurface depth have low level of available zinc. This indicates that some of the soils in the study area were moderate in available zinc as the values were above the critical limit of $0.80 \mathrm{mg}$ $\mathrm{kg}^{-1}$ reported by Esu (1991).

Table.1 Physical Properties of the Study Area

\begin{tabular}{|c|c|c|c|c|c|c|c|c|}
\hline & \multicolumn{3}{|c|}{ Surface soil (0-20 cm) } & \multicolumn{4}{c|}{ Subsurface soil (20-50 cm) } \\
\hline & Sand & Silt & Clay & TC & Sand & Silt & Clay & TC \\
\hline Sample & $\%$ & $\%$ & $\%$ & & $\%$ & $\%$ & $\%$ & \\
\hline $\mathbf{1}$ & 80.2 & 7.5 & 12.3 & SL & 72.8 & 11.4 & 15.8 & SL \\
\hline $\mathbf{2}$ & 78.0 & 9.5 & 12.5 & SL & 70.8 & 10.8 & 18.4 & SL \\
\hline $\mathbf{3}$ & 68.1 & 13.0 & 18.9 & SL & 64.4 & 15.2 & 20.4 & SCL \\
\hline $\mathbf{4}$ & 66.5 & 14.2 & 19.3 & SL & 64.1 & 14.3 & 21.6 & SCL \\
\hline $\mathbf{5}$ & 68.0 & 13.0 & 19.0 & SL & 65.2 & 14.4 & 20.4 & SCL \\
\hline $\mathbf{6}$ & 79.8 & 6.0 & 14.2 & SL & 76.1 & 6.5 & 17.4 & SL \\
\hline $\mathbf{7}$ & 68.7 & 14.0 & 17.3 & SL & 64.9 & 14.5 & 20.6 & SCL \\
\hline $\mathbf{8}$ & 55.4 & 17.4 & 27.2 & SCL & 58.3 & 13.3 & 28.4 & SCL \\
\hline $\mathbf{9}$ & 58.2 & 14.6 & 27.2 & SCL & 60.2 & 13.2 & 26.6 & SCL \\
\hline $\mathbf{1 0}$ & 63.2 & 8.1 & 28.7 & SCL & 61.1 & 11.3 & 27.6 & SCL \\
\hline Min & 55.4 & 6.0 & 12.3 & & 58.3 & 6.5 & 15.8 & \\
\hline Max & 80.2 & 17.4 & 28.7 & & 76.1 & 15.2 & 28.4 & \\
\hline Mean & 68.5 & 11.7 & 19.8 & & 66.0 & 12.2 & 21.8 & \\
\hline
\end{tabular}

$\mathrm{TC}=$ Textural class, $\mathrm{LS}=$ Loamy Sand, $\mathrm{SCL}=$ Sandy clay loam 
Table.2 Chemical Properties of surface $(0-20 \mathrm{~cm})$ soil of the study Area

\begin{tabular}{|c|c|c|c|c|c|c|c|c|c|c|c|c|c|}
\hline & $\mathbf{p H}$ & $\mathbf{E C}$ & O.C & $\mathbf{T N}$ & Av $P$ & $\mathbf{C a}$ & Mg & $\mathbf{K}$ & $\mathbf{N a}$ & CEC & TEA & ECEC & $\mathbf{Z n}$ \\
\hline Sample & $1: 2.5$ & $\mathrm{dSm}^{-1}$ & $\%$ & $\%$ & $\mathrm{mg} \mathrm{kg}^{-1}$ & \multicolumn{7}{|c|}{$\operatorname{cmol}(+) \mathrm{kg}^{-1} \longrightarrow$} & $\mathrm{mg} / \mathrm{kg}$ \\
\hline 1 & 6.6 & 0.06 & 0.43 & 0.09 & 9.8 & 9.6 & 1.20 & 0.41 & 0.10 & 11.31 & 0.40 & 11.71 & 1.35 \\
\hline 2 & 6.5 & 0.10 & 0.25 & 0.12 & 22.4 & 7.2 & 0.75 & 0.55 & 0.17 & 8.67 & 0.30 & 8.97 & 1.33 \\
\hline 3 & 6.1 & 0.05 & 0.27 & 0.08 & 5.6 & 8.6 & 1.00 & 0.40 & 0.14 & 10.14 & 0.20 & 10.34 & 0.78 \\
\hline 4 & 6.3 & 0.11 & 0.19 & 0.11 & 42.0 & 6.0 & 3.00 & 0.45 & 0.18 & 9.63 & 0.20 & 9.83 & 1.32 \\
\hline 5 & 6.0 & 0.07 & 0.60 & 0.10 & 20.0 & 9.2 & 1.00 & 0.60 & 0.16 & 10.96 & 0.20 & 11.16 & 1.18 \\
\hline 6 & 6.9 & 0.20 & 0.34 & 0.09 & 16.1 & 8.4 & 4.20 & 0.44 & 0.19 & 13.23 & 0.40 & 13.63 & 1.07 \\
\hline 7 & 6.2 & 0.22 & 0.49 & 0.13 & 9.1 & 8.0 & 3.25 & 0.36 & 0.16 & 11.77 & 0.30 & 12.07 & 0.18 \\
\hline 8 & 6.6 & 0.13 & 0.25 & 0.14 & 14.0 & 6.8 & 0.80 & 0.61 & 0.15 & 8.36 & 0.20 & 8.56 & 1.68 \\
\hline 9 & 6.9 & 0.14 & 0.34 & 0.09 & 7.0 & 9.6 & 0.85 & 0.52 & 0.19 & 11.16 & 0.40 & 11.56 & 1.71 \\
\hline 10 & 6.3 & 0.18 & 0.30 & 0.11 & 14.0 & 8.4 & 1.00 & 0.42 & 0.12 & 9.94 & 0.20 & 10.14 & 0.96 \\
\hline Min & 6.0 & 0.05 & 0.19 & 0.08 & 5.6 & 6.0 & 0.75 & 0.36 & 0.10 & 8.36 & 0.20 & 8.56 & 0.18 \\
\hline Max & 6.9 & 0.22 & 0.60 & 0.14 & 42.0 & 9.6 & 4.20 & 0.61 & 0.19 & 13.23 & 0.40 & 13.63 & 1.71 \\
\hline Mean & 6.4 & 0.13 & 0.35 & 0.11 & 17.3 & 8.1 & 1.83 & 0.48 & 0.15 & 10.56 & 0.28 & 10.85 & 1.12 \\
\hline
\end{tabular}

$\mathrm{EC}=$ electrical conductivity, O.C = organic carbon, $\mathrm{TN}=$ Total Nitrogen, Av.P = Available Phosphorus,

$\mathrm{CEC}=$ cation exchange capacity, TEA $=$ Total exchangeable acidity, ECEC $=$ Effective cation exchange capacity, $\mathrm{Zn}=\mathrm{Zinc}$ 
Table.3 Chemical Properties of subsurface $(20-50 \mathrm{~cm})$ soil of the study Area

\begin{tabular}{|c|c|c|c|c|c|c|c|c|c|c|c|c|c|}
\hline & pH & EC & O C & $\mathbf{T N}$ & Av $P$ & $\mathbf{C a}$ & Mg & $\mathbf{K}$ & $\mathbf{N a}$ & TEB & TEA & ECEC & $\mathbf{Z n}$ \\
\hline Sample & $1: 2.5$ & $\mathrm{dSm}^{-1}$ & $\%$ & $\%$ & $\mathrm{mg} \mathrm{kg}^{-1}$ & \multicolumn{7}{|c|}{$\operatorname{cmot}_{(+)} \mathrm{kg}^{-1} \longrightarrow$} & $\mathrm{mg} \mathrm{kg}^{-1}$ \\
\hline 1 & 5.9 & 0.09 & 0.34 & 0.08 & 8.0 & 7.0 & 1.16 & 0.40 & 0.12 & 8.68 & 0.30 & 8.98 & 2.14 \\
\hline 2 & 6.8 & 0.10 & 0.27 & 0.10 & 18.2 & 6.7 & 0.65 & 0.45 & 0.15 & 7.95 & 0.40 & 8.35 & 1.29 \\
\hline 3 & 6.7 & 0.08 & 0.20 & 0.08 & 6.0 & 7.3 & 1.01 & 0.41 & 0.15 & 8.87 & 0.20 & 9.07 & 2.71 \\
\hline 4 & 6.5 & 0.14 & 0.17 & 0.10 & 19.0 & 5.5 & 2.30 & 0.42 & 0.17 & 8.39 & 0.40 & 8.79 & 1.29 \\
\hline 5 & 6.1 & 0.07 & 0.35 & 0.12 & 15.2 & 7.1 & 1.00 & 0.53 & 0.16 & 8.79 & 0.30 & 9.09 & 1.17 \\
\hline 6 & 6.5 & 0.15 & 0.30 & 0.09 & 13.3 & 8.1 & 3.30 & 0.41 & 0.18 & 11.99 & 0.40 & 12.39 & 1.35 \\
\hline 7 & 6.8 & 0.11 & 0.34 & 0.11 & 8.5 & 6.8 & 3.20 & 0.32 & 0.18 & 10.50 & 0.20 & 10.70 & 0.32 \\
\hline 8 & 6.7 & 0.13 & 0.24 & 0.12 & 11.0 & 6.1 & 0.75 & 0.56 & 0.17 & 7.58 & 0.40 & 7.98 & 1.25 \\
\hline 9 & 6.1 & 0.17 & 0.30 & 0.10 & 8.0 & 8.6 & 0.80 & 0.41 & 0.18 & 9.99 & 0.20 & 10.19 & 0.39 \\
\hline 10 & 6.7 & 0.14 & 0.25 & 0.09 & 11.0 & 8.0 & 0.95 & 0.38 & 0.11 & 9.44 & 0.20 & 9.64 & 1.28 \\
\hline Min & 5.9 & 0.07 & 0.17 & 0.08 & 6.0 & 5.5 & 0.65 & 0.32 & 0.11 & 7.58 & 0.20 & 7.98 & 0.32 \\
\hline Max & 6.8 & 0.17 & 0.35 & 0.12 & 19.0 & 8.6 & 3.30 & 0.56 & 0.18 & 11.99 & 0.40 & 12.39 & 2.71 \\
\hline Mean & 6.5 & 0.12 & 0.27 & 0.10 & 11.9 & 7.1 & 1.59 & 0.43 & 0.16 & 9.31 & 0.30 & 9.63 & 1.35 \\
\hline
\end{tabular}

$\mathrm{EC}=$ electrical conductivity, O.C = organic carbon, TN = Total Nitrogen, Av.P = Available Phosphorus,

$\mathrm{CEC}=$ cation exchange capacity, TEA $=$ Total exchangeable acidity, ECEC $=$ Effective cation exchange capacity, $\mathrm{Zn}=\mathrm{Zinc}$ 
Table.4 Correlation analysis (r) between Zinc and soil properties

\begin{tabular}{|c|c|c|c|}
\hline \multicolumn{2}{|c|}{ Surface $(0-20 \mathrm{~cm})$ soil } & \multicolumn{2}{|c|}{ Subsurface $(20-50 \mathrm{~cm})$ soil } \\
\hline Soil property & 'r' value & Soil property & 'r' value \\
\hline Sand $(\%)$ & 0.258 & Sand (\%) & 0.299 \\
\hline Silt (\%) & 0.153 & Silt (\%) & 0.017 \\
\hline Clay (\%) & 0.260 & Clay $(\%)$ & 0.382 \\
\hline pH & 0.550 & $\mathrm{pH}$ & 0.054 \\
\hline $\mathrm{EC}\left(\mathrm{dS} \mathrm{m}^{-1}\right)$ & 0.382 & $\mathrm{EC}\left(\mathrm{dS} \mathrm{m} \mathrm{m}^{-1}\right)$ & 0.524 \\
\hline O.C (\%) & 0.345 & $\mathrm{OC}(\%)$ & -0.366 \\
\hline TN $(\%)$ & 0.054 & $\mathrm{TN}(\%)$ & $-0.634 *$ \\
\hline $\operatorname{Av} P\left(\mathrm{mg} \mathrm{kg}^{-1}\right)$ & 0.216 & $\mathrm{Av} P\left(\mathrm{mg} \mathrm{kg}^{-1}\right)$ & -0.180 \\
\hline $\mathrm{Ca}\left(\mathrm{cmol}(+) \mathrm{kg}^{-1}\right)$ & 0.043 & $\mathrm{Ca}\left(\mathrm{cmol}(+) \mathrm{kg}^{-1}\right)$ & -0.130 \\
\hline $\operatorname{Mg}\left(\operatorname{cmol}(+) \mathrm{kg}^{-1}\right)$ & 0.455 & $\operatorname{Mg}\left(\mathrm{cmol}(+) \mathrm{kg}^{-1}\right)$ & -0.277 \\
\hline$K\left(\operatorname{cmol}(+) \mathrm{kg}^{-1}\right)$ & $0.702 *$ & $\mathrm{~K}\left(\mathrm{cmol}(+) \mathrm{kg}^{-1}\right)$ & 0.194 \\
\hline $\mathrm{Na}\left(\mathrm{cmol}(+) \mathrm{kg}^{-1}\right)$ & 0.147 & $\mathrm{Na}\left(\mathrm{cmol}(+) \mathrm{kg}^{-1}\right)$ & 0.525 \\
\hline $\left.\operatorname{CEC~(cmol~(+)~} \mathrm{kg}^{-1}\right)$ & 0.383 & TEB (cmol (+) $\left.\mathrm{kg}^{-1}\right)$ & -0.312 \\
\hline TEA $\left(\operatorname{cmol}(+) \mathrm{kg}^{-1}\right)$ & 0.141 & TEA $\left(\operatorname{cmol}(+) \mathrm{kg}^{-1}\right)$ & 0.080 \\
\hline
\end{tabular}

$\mathrm{EC}=$ electrical conductivity, O.C $=$ organic carbon, Av.P = Available Phosphorus,

$\mathrm{TN}=$ Total Nitrogen, $\mathrm{CEC}=$ cation exchange capacity, TEA $=$ Total exchangeable acidity, $\mathrm{Zn}=$ Zinc. $*=$ significant at $5 \%$

\section{Relationship between extractable zinc and other soil properties}

The relationship between available zinc and some soil properties is presented in Table 4. In surface soil zinc correlated positively with potassium $(\mathrm{r}=0.702 *)$ (Table 4$)$ and showed no significant relationship with most of soil properties. Oyinlola and Chude (2010) also reported a non significant correlation between zinc and pH, O.C, and ECEC, but significantly correlated with sand, silt, clay, total $\mathrm{N}$ and available $\mathrm{P}$.

In subsurface soil zinc correlated negatively with Total $\mathrm{N}(\mathrm{r}=-0.634 *)$, this is contrary to the to the result of Oyinlola and Chude (2010) who reported a positive correlation between zinc and total $\mathrm{N}$

Results from present study indicate that the soils were generally sandy clay to sandy clay loam in texture, slightly acidic and low in organic carbon, Total $\mathrm{N}$ and low to medium in exchangeable bases and available zinc content.

It could be recommended that application of inorganic fertilizers plus zinc and organic material should be encourage improving the fertility status of the soil.

\section{References}

Adebayo, A. A., and A. L. Tukur (1999). Adamawa start in Maps. Paraclete Pub Yola, Nigeria

Alam, S. M., and S. Raza. 2001. Micronutrient Fertilizers. Pakistan Journal of Biological Sciences. 4(11): 1446 - 1450.

Bapetel, U., Isa, S. S., Tahir A. M., and Abdulkadir, N. A. (2021).Assessment of Fertility Status of Soil of Geriyo Irrigation Project, Adamawa State, Nigeria. Nigerian Journal of Tropical Agriculture. 21: 102 111

Bray, R. H., and A. Kurtz (1945). Determination of Total, Organic, and Available forms of Phosphorus in soil. Soil Science. 59: $39-45$

Bremner, J. M. (1996). Total Nitrogen. Sparks, D. 
L. (ed) Methods of Soil analysis: Parts, Chemical Methods. 2nd ed, SSSA book series No. 5, SSSA, Madison, Wl, 1085 1125

Enwezor, W. O., Udo, E. J. Ayotade, K. A. Adepetu, J. A., Chude, V. O. (eds.) (1990). A review of soil and fertilizer use in Nigeria. In FPDD. Literature review on soil fertility investigations in Nigeria (Five Volumes). Federal Ministry of Agriculture and Natural Resources, Lagos. 281 pp.

Esu, I. E., (1991). Detailed soil survey of NIHORT farm at Bunkure, Kano State, Nigeria. Institute of Agricultural Research, Zaria. $72 \mathrm{pp}$

FFD (Federal Fertilizer Department). (2012). Fertilizer Use and Management Practices for Crops in Nigeria. 4rd Ed. Pp 57 - 63. FFD/FMARD, Abuja, Nigeria.

Gee, G. W., and J. W. Bauder. (1986). Particle Size Analysis. In: A. Klute (ed). Methods of Soil Analysis. Part 1. 2nd Ed. Pp 383-411. Agronomy Monograph 9. American Society of Agronomy and Soil Science Society of America, Madison, Wisconsin.

Grant, W. T. (1982). Exchangeable Cations and Exchangeable Acidity. In: Page, A.L. (eds). Methods of Soils Analysis Part 2. Chemical and Microbiological Properties. 2nd Ed. Agronomy Monograph 9. American Society of Agronomy and Soil Science Society of America, Madison, Wisconsin, USA

Isa, S. S. (2017). The Fertility Assessment of Geriyo Floodplain Soils of Yola North Local Government Area, Adamawa State Nigeria. Unpublished B.Tech Project, Faculty of Agriculture, Modibbo Adama University, Yola. 31p

Lombin, G. (1983). Evaluating the micronutrients fertility of Nigeria's semi-arid savanna soils. II Zinc. Soil Science 136: 42 - 47

Musa, H. (2006). Characterisation and Classification of the Soil of School of
Agriculture and Agricultural Technology, Yola. Unpublished M. Tech Thesis, School of Agriculture and Agricultural Technology, Federal University of Technology, Yola.

Mustapha, S., N. Voncir, S. Umar. and N. A. Abdulhamid (2011). Status and Distribution of some Available Micronutrients in thr Haplic usterts of Akko Lcal Government Area, Gombe State, Nigeria. International Journal of Soil Science. 6 (4): 267 - 274

Nazif, W., S. Perveen and I. Saleem, (2006). Status of micronutrients in soils of District Bhimber (Azad Jammu and Kashmir). $J$. Agric. Biol. Sci., 1: 35 - 40.

Nelson, D. W. and Sommers, L. E (1982). Total Organic carbon, organic matter. In: Pages, A. L., Miller R. H and Kenney, D. R. (Eds). Methods of Soil Analysis: part 2 Ameri. Soc. Agron., Madison, Wisconsin,. pp.539 - 579

Osiname, O. A., E. E. Schulte, and R. B. Corey (1973). Soil test for available copper and zinc in soils of western Nigeria. Journal of Science Food Agric. 24: 1341 - 1349

Oyinlola, E. Y., and V. O. Chude. (2010). Status of Available Micronutrients of the Basement Complex Rock - Derived Alfisols in Northern Nigeria Savannah. Tropical and Subtropical Agroecosystems. 12: 229 - 237

Schulte, E. E. (2004). Soil and Applied Zinc. Understanding Plant Nutrients. University of Wisconsin Extension Publication No. A 2527. http://learningstore.uwex.edu/pdf/A2527.pdf

Sillanpää, M. (1982). Micronutrients and the nutrient status of soils. A Global Study, FAO Soils Bulletin. No. 48. FAO, Rome, Italy.

Voncir, N., S. Mustapha, V. A. Tenebe, A. L. Kumo and S. Kushwaha, (2008). Content and profile distribution of extractable zinc ( $\mathrm{Zn}$ ) and some physicochemical properties of soil along a toposequence at Bauchi, Northern Guinea Savanna of Nigeria. Int. J. Soil Sci., 3: $62-68$.

\section{How to cite this article:}

Bapetel, U., M. L. Bubarai, A. M. Tahir and Abdulkadir, N. A. 2021. Levels of Available Zinc in Soil of Teaching and Research Farm Modibbo Adama University, Yola, North East Nigeria. Int.J.Curr.Microbiol.App.Sci. 10(09): 448-455. doi: https://doi.org/10.20546/ijcmas.2021.1009.052 